\title{
Testosterone and left ventricular diastolic function in men with heart failure
}

\section{Viktor Čulić* \\ Željko Bušić \\ Marija Bušić \\ Marina Jurić-Paić \\ Adrijana Livaja}

University of Split School of Medicine, University Hospital Centre Split, Split, Croatia
RECEIVED:

April 9, 2015

ACCEPTED:

April 20, 2015
KEYWORDS: echocardiography, diastolic dysfunction, men, myocardial infarction, smoking, testosterone CITATION: Cardiol Croat. 2015;10(3-4):59. | DOI: http://dx.doi.org/10.15836/ccar.2015.59

ORCID: Viktor Čulić, http://orcid.org/0000-0002-4026-0195 • Željko Bušić, http://orcid.org/0000-0001-5877-3602 • Marija Bušić, http://orcid.org/0000-0003-4216-2430 • Marina Jurić-Paić, http://orcid.org/0000-0003-4117-0105• Adrijana Livaja, http://orcid.org/0000-0003-2408-0634

*ADDRESS FOR CORRESPONDENCE: Viktor Čulić, Zavod za bolesti srca i krvnih žila, Klinički bolnički centar Split, Šoltanska 1, HR-21000 Split, Croatia. Phone: +385-21-557-393. E-mail: viktor.culic@st.t-com.hr

|l|||||||||||||||||||||||||||||||||||||||||||||||||||||||||||||||||||||||||||||||||||||||||||||||||||||||||||||||||||||||||

BACKGROUND: Previous studies found no correlation between serum testosterone levels (TL) and left ventricular (LV) ejection fraction, but the role of testosterone in diastolic dysfunction (DD) is less understood.

METHODS: Male patients hospitalized because of acute HF at the Department of Cardiology, University Hospital Center Split-Križine between December 2011, and March 2014 were enrolled. The diagnosis was established according to clinical presentation and echocardiographic findings of either systolic (LV ejection fraction $<45 \%$ assessed by the Simpson method) or DD. Color M-mode, pulsed-wave Doppler from the apical four-chamber view and tissueDoppler imaging parameters of diastolic LV function were measured to assess the severity of DD according to four basic grades

RESULTS: Of the 121 patient, 31 (25.6\%) had previous MI. They significantly more often used aspirin, loop diuretic, spironolactone or beta-blocker and have a significantly lower serum total TL and higher GFR ( $p<0.05$ in all cases) compared to patients without a previous MI. There were no differences in average age, LV ejection fraction, cardiovascular risk factors or prehospital use of digoxin, angiotensin converting enzyme-inhibitor, angiotensin II receptor I blocker, calcium channel antagonist or statin.

DD showed a significant inverse correlation with total TL $(r=-0.222, p=0.001)$ in all patients, and the same trend was present separately in both men with $(r=-0.334, p=0.07)$ and without $(r=-0.198, p=0.06)$ previous MI. Multivariate analysis revealed that in all patients, both low total TL $(B=-0.244, p=0.006)$ and smoking $(B=-0.255, p=0.004)$ were significant predictors of DD severity. Among post-infarction patients only smoking ( $(=0.604, p=0.0002)$ remained a strong independent predictor whereas in their counterpart group it was only low total TL ( $\beta=-0.213, p=0.047)$

CONCLUSIONS: The results of the present report suggest that lower TL could be an important factor in the development of DD in men with HF without previous MI. In HF patients who have had a MI, smoking seems to be the chief factor in the progression of DD.
Cardiologia Croatica 2015:10(3-4):59. 